\title{
The Influence of Competence and Organizational \\ Commitment on Work Satisfaction and Their Impact on Performance Employee (Study in PT. KAI Divre III, South Sumatera)
}

\author{
Choiriyah \\ Sekolah Pascasarjana, Universitas Pancasila \\ Universitas Muhammadiyah Palembang \\ E-mail: choiriyahmp@yahoo.co.id
}

Wibowo

Universitas Prof. Dr. Moestopo (Beragama)

Hanes Riyadi

Institut Bisnis dan Informasi Kwik Kian Gie

Husein Umar

Institut Bisnis dan Informasi Kwik Kian Gie

Received: Dec. 11, 2018 Accepted: Jan. 10, 2019 Online published: Jan. 28, 2019

doi:10.5296/ijhrs.v9i1.14037ＵRL: https://doi.org/10.5296/ijhrs.v9i1.14037

\begin{abstract}
The aim of this research is to analyze the effect of Competence and Organizational Commitment on Work Satisfaction and their impact on Employee Performance: A Case Study conducted in PT. KAI DIVRE III Palembang. The research design used in the research is explanatory design which explains the causal relationship among variables. The research location is in Palembang City, South Sumatra Province while the research objects is PT. KAI DIVRE III Palembang with 200 persons as employees. This dissertation used primary
\end{abstract}


datafrom questionnaire filled out by the respondents. The sample selection used simple random sampling. The method of research used descriptive statistics using SPSS and Structural Equation Modeling (SEM) using Lisrel. The descriptive analysis shows that the level of Competence, Organizational Commitment, Work Satisfactionand Employee Performance is at a positive level. The results stated that the Competence has no significant impact on Work Satisfaction, Competence has significant impact on Employee Performance, Organizational Commitment has significant impact on Work Satisfaction, Organizational Commitment has significant impact on Employee Performance, and Work Satisfaction has significant impact on Employee Performance.

Keywords: competence, commitment, satisfaction, performance

\section{Introduction}

The development of the state apparatus is directed at improving the quality, efficiency and effectiveness of all government administrative arrangements, including enhancing capacity and creativity, service, exemplary and welfare of its officers. In facing the era of globalization where competition is fierce increasingly and technology is growing rapidly demanding organizations or companies to have the ability and skills in carrying out work. Labor or employees are very important factors in achieving the goals of an organization or company effectively and efficiently. Therefore, there is a need for encouragement for employees to work so that employees are passionate to do their job. Attitude is an evaluative statement liked or disliked related to objects, people, or events.

The role of human resources will be increasingly valued, especially in terms of human resource competencies in business management. Appreciation for the competence of human resources is indeed necessary because it will affect the effectiveness of business activities in the process of adaptation and competence to deal with discontinuous environmental changes.

Factors that are thought to influence the performance of employees in accordance with what was stated by Robbins (2003), said that employee performance is a function of ability, motivation and opportunity. Thus, it can be seen that organizational commitment is a function of competence, and work motivation, while performance is a function of competence, organizational commitment and work motivation. Rice (1999) shows that emotional competence has a positive and significant effect on the performance and improvement of the quality of customer servants in banking companies. Shore and Martin (1989) managed to prove job satisfaction and organizational commitment had a positive and significant effect on employee performance and employee turnover

The development of the transportation sector which covers land, sea or air aims to improve broader, orderly, safe, fast, smooth and efficient transportation capabilities at a cost affordable to the public. For this reason, it is necessary to develop the existing transportation potential and improve service quality and efficiency in business in the land sector. This goal can be realized if every company or business entity engaged in the transportation sector carries out various innovative activities or businesses to maintain its life, develop and obtain optimal profits. 


\section{MInstitute ${ }_{\text {Int" }}^{\text {Macrothink }}$}

International Journal of Human Resource Studies

ISSN 2162-3058

2019, Vol. 9, No. 1

The rapid development of the business world, the role of Human Resources (HR) is felt to be increasingly important for business entities. The quality of an organization's human resources determines the success or failure of achieving organizational goals. Human resources are the most vital organizational resources and are recognized as the most valuable assets for business entities. PT. KAI Divre III South Sumatra is one company that attaches great importance to the quality of its HR.

Some phenomena that show the performance of employees of PT. KAI Divre III South Sumatra is still low, namely: (1) Performance of employees of PT. KAI Divre III South Sumatra based on observations has not been so good, even though in its activities PT. Kereta Api is required to be able to provide the best service to the community, (2) Performance of employees of PT. KAI Divre III South Sumatra has not been optimal, there are still some employees who think that they have not been able to fulfill what is standardized, both from the quality and quantity of work, reliability and personal quality, (3) Attitudes and behavior of employees of PT. KAI Divre III South Sumatra, which often complains or does not behave adult in work, does not comply with applicable rules, evades part of its responsibilities and feels bored in work. All of this is a symptom that employees feel job dissatisfaction from employees of PT. KAI Divre III South Sumatra, (4) The level of employee job satisfaction that occurs in employees of PT. KAI Divre III South Sumatra is suspected that there are several things that cause it, including the competencies that employees have not in accordance with the demands of work, systems and managerial aspects of career development that are still weak, (5) Employees competence of PT. KAI Divre III South Sumatra looks inconsistent with self-control and inconsistent in carrying out tasks, (6) Performance is also influenced by job satisfaction. An employee will get job satisfaction when feeling a positive job. High job satisfaction will motivate employees to work better. For this reason, employee commitment is needed for the organization. With the commitment, job satisfaction will increase, (7) The organizational commitment of PT. KAI Divre III South Sumatra employees can be seen from work experience, organizational size and trust in the company, (8) Employee discipline, some employees cannot be controlled because they work more in the field and absenteeism is done online that is directly connected to the head office of PT. KAI in Bandung, (9) Compensation in the form of incentives received, often felt by some employees not according to the amount based on the calculation of the employee concerned.

The purpose of this research is to test and analyze: (1) Effect of competence on employee job satisfaction, (2) Effect of competence on employee performance, (3) Effect of organizational commitment on employee job satisfaction, (4) Effect of organizational commitment on employee performance, (5) Effect of job satisfaction on employee performance.

\section{Literature Review}

\subsection{Concept of Employee Performance}

According to Armstrong and Baron (2005) performance is the result of work that has a strong relationship with the organization's strategic goals, customer satisfaction and economic contribution. According to Bernardin and Russel (2003), performance is a record of the results obtained from certain job functions or certain activities over a period of time, according to 
Mathis and Jackson (2004) employee performance is what is done and not done by employees. Thus, employee performance is the quality and quantity of the work of a person or group in carrying out their duties and obligations during a certain period of time due to natural abilities or abilities of the learning process and the desire for achievement.

According to Ruky (2009), there are a number of objectives that can usually be achieved by an organization by implementing a performance management system, namely: 1) Improving employee work performance, both individually and as a group, 2) Increased employee performance individually, in turn, will drive the performance of human resources as a whole, which is reflected in increases in productivity, 3) Stimulate personal interest and development with the aim of improving work results and personal achievements and latent potential of employees, 4) Helping organizations develop employee development and training programs more effective, 5) Providing tools / facilities to compare the work performance of employees with the level of salary or compensation as part of a good policy and reward system, 6) Providing opportunities for employees to express their feelings about work or things that are related.

From the expert's opinion, the definition of employee performance in the individual context used in this study is the direct supervisor's assessment of the work results of employees including work quality, work quantity, reliability and personal quality. Measures of employee performance in this study then adapted measurements from Dessler (2005); Benerdin and Russel (2003); Neal Jr. (2003) includes: (1) Quality and quantity of work; (2) Reliability; (3) Personal quality .

\subsection{Job Satisfaction}

According to Mathis and Jackson (2004) states that job satisfaction is the emotional state of employees where there is or does not occur a meeting point between the value of employee retribution from a company and the level of service reciprocity that is desired by the employee, either financial or non-financial.

Wexley and Yukl (2010) state that job satisfaction is an individual matter and the problem of job satisfaction can affect employee absenteeism, labor turnover, morale, complaints and other vital personnel issues. This means job satisfaction as a person's feelings for his job. Based on the opinions of several experts above it can be said that job satisfaction (job satisfaction) is a general attitude that an individual has regarding his work. A person's attitude towards his work reflects a pleasant and unpleasant experience in his work and his hopes for future experiences.

Luthan and Farlin (2002) divide job satisfaction into two types, namely: 1) Functional satisfaction is satisfaction obtained from achieving or completing tasks that are the responsibility of employees, and 2) Psychological satisfaction is satisfaction obtained from the sides other than fulfilling duties and obligations.

\subsection{Competence}

Sanghi (2007) states that 'competence' means a skill and standard of performance achievement, while "competency" refers to the behavior to be achieved. In other words, one term describes 
what someone can do, while another focuses on how someone does something. Therefore there is a link between the two, namely the application of competent expertise tends to make one action in a competent manner and vice versa.

Competence concerns the authority of each individual to carry out a task or make a decision according to his role in the organization that is relevant to the knowledge, skills and abilities possessed, so that competencies will be strongly related to the performance they produce. Spencer \& Spencer (1993) defines competency as a basic characteristic of an individual that relates to causation for effective criteria and / or superior performance in a job or situation.

While Michael Zwell (2000) defines the concept of competency in a simple way is a good way to break behavior into its components in order to achieve organizational goals. According to Mathis \& Jackson (2009) competence is a basic characteristic that can be associated with improving individual or team performance.

\subsection{Organizational Commitment}

Organizational commitment is one of the behaviors in organizations that are discussed and studied a lot, both as dependent variables, independent variables, and mediator variables. This is partly because organizations need employees who have high organizational commitment so that the organization can continue to survive and improve the services and products it produces. Employees who have high organizational commitment are employees who are more stable and more productive so that in the end it is also more profitable for the organization.

According to Gibson, Ivancevich, Donnely and Konopaske (2008) that Organizational Commitment is a feeling of identification, involvement, and loyalty expressed by employees towards the organization. Riggio, Murphy and Pirozzolo (2001) state that employee commitment as all employees' feelings and attitudes towards everything related to the organization in which they work includes their work. Davis and Newstorm (2006) state employee commitment as the nature of the relationship between an organization and an individual who has a high commitment to the organization showing a strong desire to remain a member of the organization; willingness to do their best for the benefit of the organization; and trust and strong acceptance of organizational values and objectives. Compared to attachment, commitment includes active relationships between workers and employers where the worker is willing to give something of his own volition in order to support the achievement of organizational goals.

The results of the Modway study, Porter and Steers (1979), state that the dimensions of Organizational Commitment consist of: (1) The desire to maintain membership in the organization, where an employee who has a high desire reflects a high commitment too; (2) Confidence and acceptance of the values and goals of the organization, where an employee is willing to accept the values adopted by the organization and the goals of the organization, reflecting high commitment; (3) Willingness to work hard as part of the organization, where an employee who works seriously to complete his task then he has a high commitment too. 


\section{Macrothink}

International Journal of Human Resource Studies

ISSN 2162-3058 2019, Vol. 9, No. 1

Based on the formulation of research problems, theoretical concepts, and previous research, the conceptual model of this research is as shown in Figure 1.

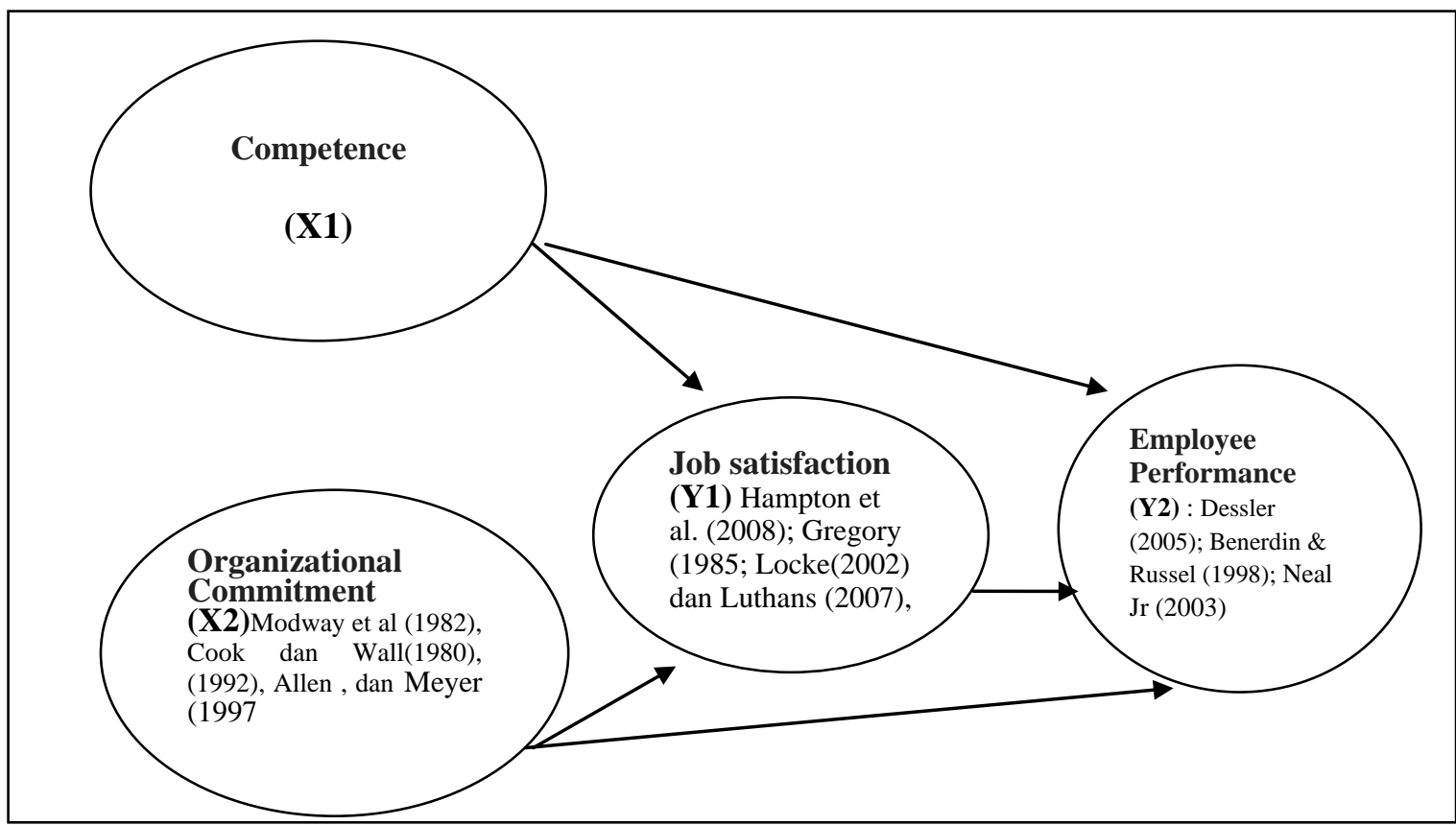

Based on the research gap relating to Competence, Organizational Commitment, Job Satisfaction, and Employee Performance, this research raises a research problem "How to improve company performance in answering these problems is proposed 5 (Five) hypotheses summarized in tiered causality models by including moderation effects presented in Figure 2 below:

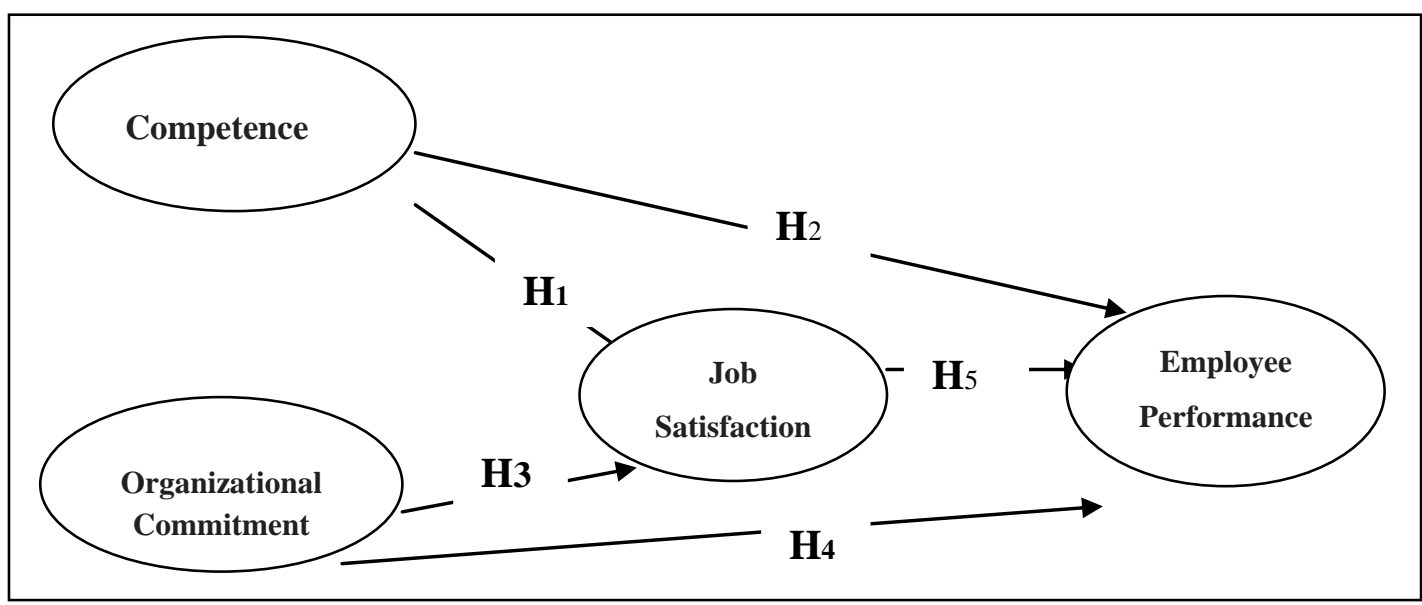

Based on the empirical research model above, the following are the hypotheses of this study: (1) There is a significant effect of Competence on employee job satisfaction, (2) There is a significant effect of Competence on employee performance, (3) There is a significant effect of Organizational Commitment on employee job satisfaction, (4) There is a significant influence of Organizational Commitment on employee performance, (5) There is a significant effect of employee job satisfaction on employee performance 


\section{Research Methodology}

This study uses a quantitative approach, namely research that uses numerical/ numerical data analysis obtained through surveys. The survey method is a method that uses a portion of the population (sample), and then from this sample is intended to describe the overall condition of the population (generalization). Through this quantitative approach, two research methods are chosen, namely descriptive and testing hypotheses.

The study design used a survey approach and cross sectional design. Survey research is research that involves sample calculations to generalize the population, while cross-sectional design is a method of collecting data where each variable is examined at the time together. Based on the level of expansion, this study seeks to explain the effect on the variables hypothesized in the model so that the approach used is a causal relationship through structural equation modeling (Structural Equation Modeling-SEM). The variables used in the study include the variables of Competence (K), Organizational Commitment (KO), Job Satisfaction $(\mathrm{KK})$ and Employee Performance (KIN).

Performance is the achievement of work results by a person, within a certain period of time, according to the responsibilities assigned to him and is a comparison between performance targets / objectives and real performance in the field in the form of quality and quantity of work results. Performance is operationalized as a result of work which includes accuracy, productivity, responsibility, reliability, utilization of time, attendance, and collaboration that employees display in carrying out their work.

The concept of job satisfaction in this study is the gap between expectations and reality received in doing work within an organization as its responsibility. If the reality is higher than expectations, then the respondent expresses satisfaction, so does the opposite. Respondents were given alternative answers to agree-disagree that those concerned were satisfied or dissatisfied.The dimensions of Job Satisfaction in this study include: 1) Workplace; 2) Socialization; 3) Work.

Starting from the description and explanation of the concepts and characteristics (dimensions) of competencies as stated in the literature review, in this study the competency theory which is used as the foundation is the competency theory of Spencer and Spencer (1993) and Dubois (2004), namely five dimensions competencies, namely: 1) Motives (motives), 2) Traits, 3) Self-concepts, 4) Knowledge, and 5) Skills.

Organizational Commitment in this study is the commitment of worker behavior that emphasizes the process by which individuals develop commitment in the form of behavior towards the organization. The dimensions of Organizational Commitment used in this study are: 1) Affective; 2) Continuance; 3) Normative.

Byrne (2010) recommends a minimum acceptable sample for SEM estimation is 100. Kline (2005) requires that the number of samples suitable for SEM estimation is> 200 for complex models. Opinion Hair et. al. (2010) also states that the minimum number of samples that is adequate for SEM estimation is 200 . 


\section{Mll Macrothink}

The population in this study are employees of PT. KAI Divre III South Sumatra. The number of employees in Divre III Sumatera Selatan is 2,295 people. In this study, sample selection techniques used proportionate simple random sampling, so that the sample size for Divre III South Sumatra offices was 19 people and for Divre 3.1 Kertapati Station was 181 people, researchers distributed 200 questionnaires to employees in the PT. KAI Divre III South Sumatra in Palembang, namely Office Staff Divre III and Sub Divre 3.1 Kertapati.

Analysis tool to test the research hypotheses that have been determined in the previous Hypothesis sub-chapters using the Structural Equation Modeling (SEM) method. To test the research model that has been proposed, namely the influence of Competence and Organizational Commitment on Job Satisfaction and its effect on Employee Performance will use the SEM analysis method. SEM (Structural Equation Modeling) is a statistical technique for multivariate analysis which among others is able to analyze indicator variables, latent variables, and measurement errors of variables. In this model, it is assumed specifically in the direction of relations between constructs (latent variables). This model can also be used to test whether the proposed theories are in accordance with empirical models. Thus, SEM analysis is in accordance with verification research that combines theory and empirical data.

\section{Findings and Discussions}

\subsection{Inter Variable Effect Analysis}

Measurement Model Test (Measurement Model)

This analysis is carried out on all constructs (the relationship between latent variables and observation variables) separately or partially through evaluation of: construct validity (validity) and reliability (construct). The following are the test results for each construct variable.

Test of Job Satisfaction Test

The following two computer outputs are the test results of the construct variable Job Satisfaction in the form of the amount of loading factor and statistical value $t$.

Loading Factor

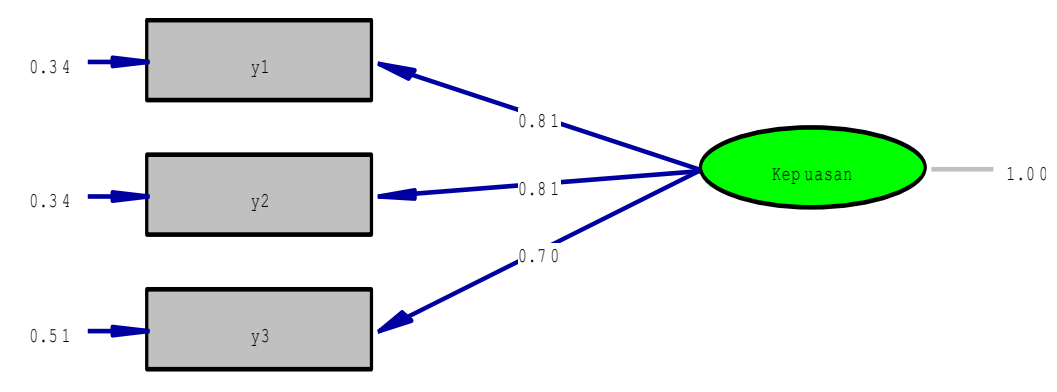

Chi-Square $=0.00, \mathrm{df}=0, \mathrm{P}-\mathrm{value}=1.00000, \mathrm{RMSEA}=0.000$

Statistical Value t (Student) 


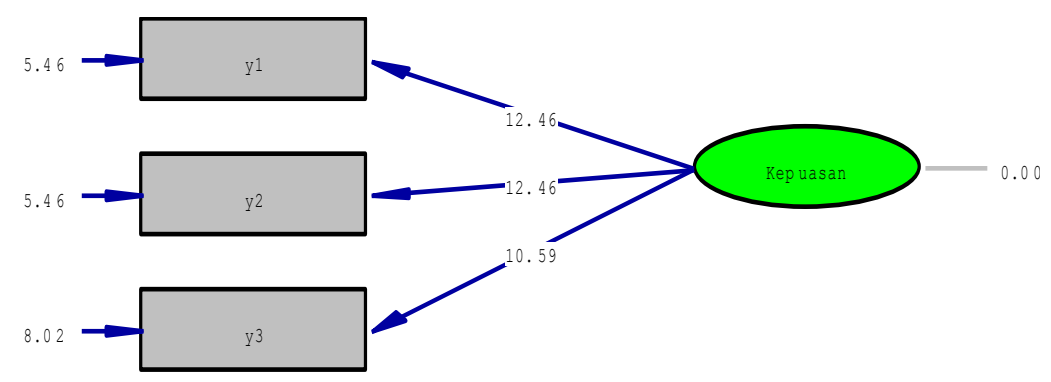

Chi-Square $=0.00, d f=0, P-v a l u e=1.00000$, RMSEA $=0.000$

Validity test based on 2 (two) outputs of this computer is known that the entire loading factor is valid because all the t-statistics are above the critical value of 1.96. Test reliability used the formula CR (Construct Reliability) and VE (Variance Extracted). The quantities required and their values are calculated as follows:

$\left(\sum \text { factor loading }\right)^{2}=(0,81+0,81+0,70)^{2}=5,38$

$\sum$ factor loading ${ }^{2}=0,81^{2}+0,81^{2}+0,70^{2}=1,95$

$\sum e_{i}=0,34+0,34+0,51=1,19$

Based on the calculated results it is known that the CR value is above the value of 0.70 and the VE value is above 0.5. Thus the latent variables of Competence and each of the observed variables are valid and reliable.

\section{Structural Test Model}

As explained, the model of the fit (goodness of fit test) will consist of three criteria. The following is the computer output that will be used for the test.

Table 1. Recapitulation of Model Match Results

\begin{tabular}{l|l|c|c}
\hline No: & \multicolumn{1}{|c|}{ Uji } & Nilai & Standar \\
\hline 1 & Chi-Square & 867,31 & \\
\hline & Probabilitas & 0,00 & $\geq 0,05$ \\
\hline 2 & Root mean Square Error of approxiamation (RMSEA) & 0,06 & $\leq 0,1$ \\
\hline 3 & Goodness of Fit Index (GFI) & 0,74 & $\geq 0,9$ \\
\hline 4 & Adjusted Goodness of Fit Index (AGFI) & 0,63 & $\geq 0,9$ \\
\hline 5 & Normed Fit Index (NFI) & 0,88 & $0-1$ \\
\hline 6 & Comparative Fit Index (CFI) & 0,72 & $\geq 0,9$ \\
\hline 7 & Incrumental Fit Index (IFI) & 0,72 & $\geq 0,9$ \\
\hline 8 & Relative Fit Index (RFI) & 0,63 & $\geq 0,9$ \\
\hline 9 & Expected Cross-Validation Index (ECVI) & 2,97 & $\leq 14,03$ \\
\hline 10 & Akaike Informasi Creterion (AIC) & 612 & $\leq 2931$ \\
\hline 11 & Consistent Akaike Information Criterion (CAIC) & 777,72 & $\leq 2996,74$ \\
\hline 12 & Pasimonous Goodness of Fit Index (PGFI) & 0,62 & $\geq 0,60$ \\
\hline 13 & Root Mean Residual (RMR) & 0,07 & $\leq 0,1$ \\
\hline
\end{tabular}




\section{Macrothink}

\subsection{Inter Variable Effect Test}

Large influence between variables

Figure 3. is a computer output in the basic model estimates, which is a complete output (hybrid) which illustrates the influence of all latent variables and observed variables, and between latent variables.

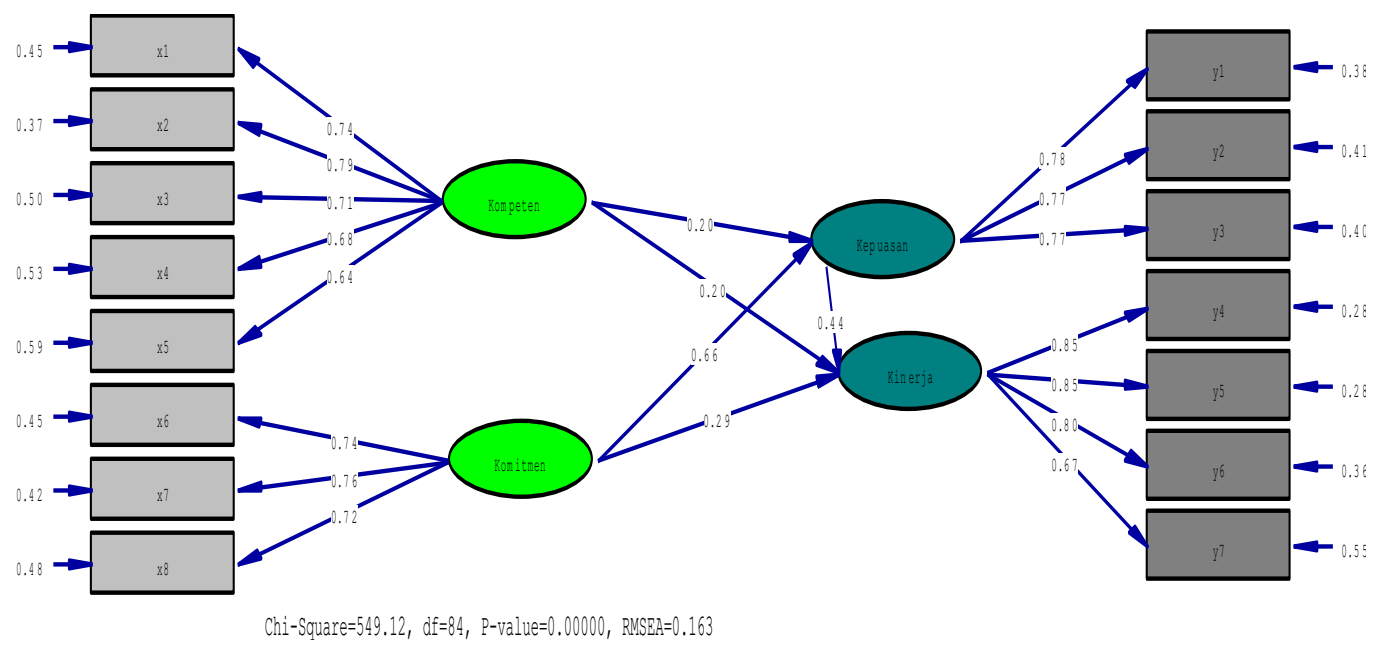

Figure 3. Complete Model of Research Results

Figure 4. is a computer output in t statistical value (basic model T-values), which is a complete output (hybrid) that illustrates the level of significance of whether the influence of all latent variables on variables is observed, and the effect of latent variables on other latent variables is significant or not.

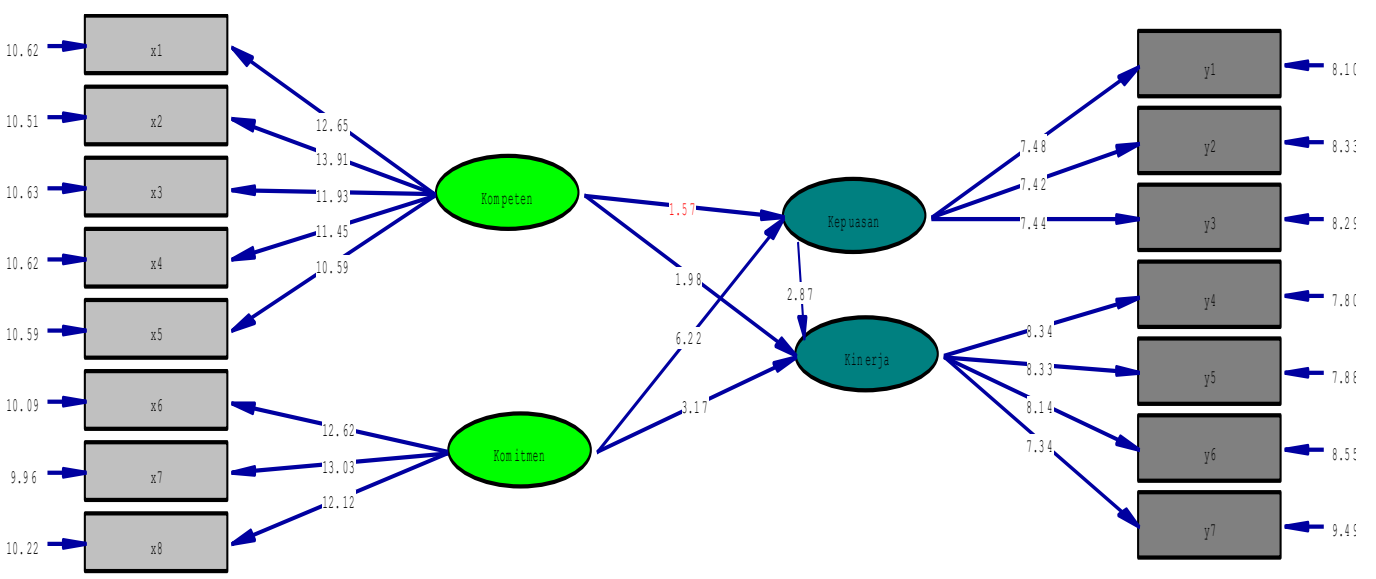

Chi-Square=549.22, df=84, P-value=0.00000, RMSER=0.163

Figure 4. Complete Model (Statistical Value t)

For analysis needs, the two images are simplified according to the research objectives and the research model. 
Figure 5. Large influence between variables

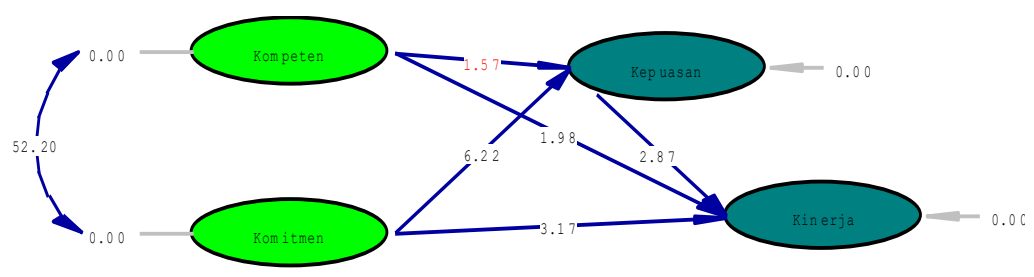

Chi-Square $=549.22, \mathrm{df}=84, \mathrm{P}-\mathrm{value}=0.00000, \mathrm{RMSEA}=0.163$

Figure 6. Statistical value t (T-values)

Based on the value of influence and the value of distribution $t$ of one variable with other variables as shown in Figure 5 and Figure 6 can be seen the effect of its significance in Table 2.

Table 2. Level of significance of influence between variables ( $t$ table 1.96)

\begin{tabular}{l|c|c|c}
\hline \multicolumn{1}{c|}{ Influence between variables } & Influence & $\begin{array}{l}\text { Value of } \\
\text { Distribution } \\
\mathrm{t}\end{array}$ & Influence \\
\hline Competence -> Job Satisfaction & 0,20 & 1,57 & Not significant \\
\hline Competence -> Performance & 0,20 & 1,98 & Significant \\
\hline $\begin{array}{l}\text { Organizational Commitment -> Job } \\
\text { Satisfaction }\end{array}$ & 0,65 & 6,22 & Significant \\
\hline $\begin{array}{l}\text { Organizational Commitment -> } \\
\text { Performance }\end{array}$ & 0,29 & 3,17 & Significant \\
\hline Job Satisfaction-> Performance & 0,44 & 2,87 & Significant \\
\hline
\end{tabular}

In addition to the form of tables, the value of influence and the value of other $t$ distributions in the form of images are presented as shown in Figure 7. 


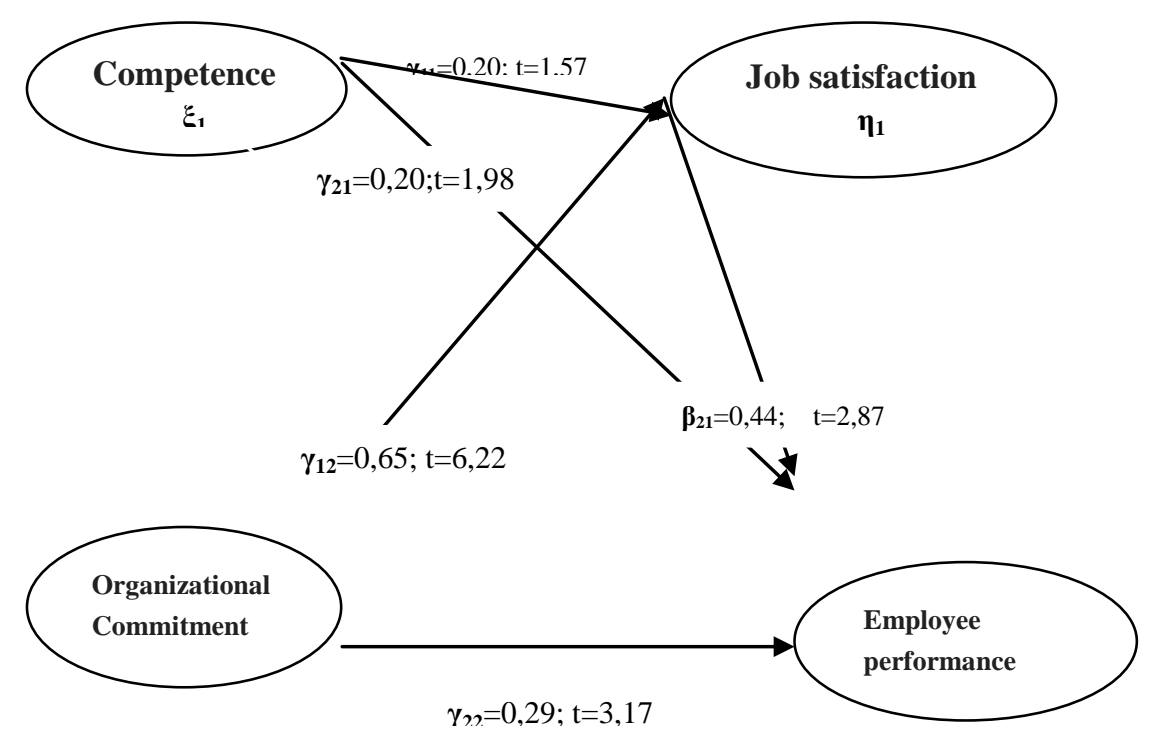

Figure 7. Research Results Model

Based on Figure 7, it can be seen the influence between the latent variables both directly and indirectly, and the value of the distribution $\mathrm{t}$.

Statistical Test

The influence of Competence on Job Satisfaction is 0.20 . The statistic value is calculated 1.57 below the $t$ table statistic (for $\alpha 5 \%$ and the 2 -way test is 1.96). Because the value of $t$ count $<\mathrm{t}$ table then the null hypothesis is accepted, so it is concluded that Competence has no effect on Job Satisfaction. Thus, the results of this study are not in accordance with the theory and several previous studies as explained in the frame of mind.

The influence of Competence on Performance is 0.20 . The statistic value of $t$ is 1.98 above the $\mathrm{t}$ table statistic (for $\alpha 5 \%$ and the 2 -way test is 1.96). Because the value of $\mathrm{t}$ count $>\mathrm{t}$ table, the null hypothesis is rejected, so it is concluded that Competence has an effect on Employee Performance. Thus, the results of this study are in accordance with the theory and several previous studies as explained in the frame of mind.

The influence of Organizational Commitment on Job Satisfaction is 0.65. The statistic value of $t$ count 6.22 is above the $t$ table statistic (for $\alpha 5 \%$ and the 2 -way test value is \pm 1.96 ). Therefore the null hypothesis is rejected, so it is concluded that Organizational Commitment influences Job Satisfaction. Thus, the results of this study are in accordance with the theory and several previous studies as explained in the frame of mind.

The influence of Organizational Commitment on Employee Performance is 0.29. The statistical value of $t$ count is 3.17 above the t table statistic (for $\alpha 5 \%$ and the 2 -way test is 1.96). Because the value of $t$ count $>t$ table, the null hypothesis is rejected, so it is concluded that Organizational Commitment influences Employee Performance. Thus, the results of this study are in accordance with the theory and several previous studies as explained in the frame of mind. 


\section{Ml Macrothink}

The influence of Job Satisfaction on Employee Performance is 0.44 . The statistic value of $t$ count 2.87 is greater than the $t$ table statistic (for $\alpha 5 \%$ and the 2-way test is 1.96). Because the value of $t$ count $>t$ table, the null hypothesis is rejected, so it is concluded that Job Satisfaction has a positive effect on Employee Performance. Thus, the results of this study are in accordance with the theory and several previous studies as explained in the frame of mind.

\subsection{Direct, Indirect and Total Influences}

The results of calculating the influences between these variables as in Table 3 .

Table 3. Direct, Indirect and Total Effects

\begin{tabular}{c|l|c|c|l|c}
\hline No. & \multicolumn{1}{|c|}{ Plot } & $\begin{array}{c}\text { Intervening } \\
\text { variable }\end{array}$ & $\begin{array}{c}\text { Direct } \\
\text { Influence }\end{array}$ & $\begin{array}{l}\text { Indirect } \\
\text { Effects }\end{array}$ & $\begin{array}{l}\text { Total } \\
\text { Influence }\end{array}$ \\
\hline 1 & $\begin{array}{l}\text { Competence -> } \\
\text { Performance }\end{array}$ & Job Satisfaction & 0,20 & $\begin{array}{c}0,20 \times 0,44= \\
0,088\end{array}$ & 0,288 \\
\hline 2 & $\begin{array}{l}\text { Commitment -> } \\
\text { Performance }\end{array}$ & Job satisfaction & 0,29 & $\begin{array}{c}0,65 \times 0,44= \\
0,28\end{array}$ & 0,57 \\
\hline
\end{tabular}

Competence directly has a significant effect on Employee Performance of 0.20; but the effect is indirectly through Job Satisfaction of 0.088. This states that the Job Satisfaction variable has a smaller role to support the influence of Competence on Employee Performance.

Commitment directly has a significant effect on Employee Performance of 0.29 but its effect is indirectly through Job Satisfaction of 0.28. This states that the Job Satisfaction variable has a smaller role to support the influence of Commitment to Employee Performance.

Based on 2 independent variables namely Competence and Commitment which have the biggest role on Job Satisfaction is Commitment. Likewise the impact on performance, that commitment becomes the biggest influence. Basically a very important commitment in the organization because commitment is the attachment of a person or group to the organization and works selflessly to achieve common goals.

Employees of PT. KAI Divre III has commitment in the field of work and obtains adequate compensation and employees are satisfied with their work, all interacting in shaping employee performance.

Prediction and Determination (r2)

Prediction of Job Satisfaction

Satisfaction $=0.20 \times$ Competence +0.65 Commitment

where the determinant value $\mathrm{R}^{2}=0.76$

This equation can predict the value of employee satisfaction if it is known the value of employee competence and the value of employee commitment. For example, if the employee competency value is 5 and the employee commitment value is 5 , then the satisfaction value is $0.2 \times 5+0.65 \times 5=4.25$. Qualitatively the satisfaction value is categorized as very satisfied. 
Determinant value R2 is 0.76 means variation in value of Competence and Commitment can explain the variation of Satisfaction only $76 \%$, the remaining $24 \%$ is contributed by other variables, for example work culture variables, work motivation and leadership.

Performance Prediction

Performance $=0.20 \times$ Competence +0.29 Commitment +0.44 Satisfaction

where the determinant value $\mathrm{R}^{2}=0.84$

This equation can predict the value of employee performance if it is known the value of employee competency, value of commitment and value of employee job satisfaction. For example, if the value of employee competency is 5 , the value of employee commitment is 5 , and employee job satisfaction is 5 , then the satisfaction value is $0.2 \times 5+0.29 \times 5+0.44 \times 5$ $=4.65$. Qualitatively the value of employee performance is in a very good category.

Determinant value R2 is 0.84 means variation in value of Competence, Satisfaction and Commitment can explain variations in employee performance only $84 \%$, the remaining $16 \%$ is contributed by other variables, for example work culture variables, work motivation and leadership, work discipline, work environment.

All research findings are discussed further. Therefore, the researcher made a direct observation to PT. KAI Divre III South Sumatra and managed to interview several employees to get further information in order to propose solutions from the findings of this study. The process of this follow-up activity is located in Divre III and Divre 3.1 Kertapati.

It is known that the ability of employees to assimilate new knowledge depends on the fact whether the employees of PT. KAI Divre III South Sumatra already has knowledge related to newly received knowledge that enables them to understand and absorb new information that is transferred to them. Based on the conditions, it is necessary for the leadership to be directly related to the employees of PT. KAI Divre III Sumatera Selatan gives more attention so that employees can take advantage of the role of libraries, socialization, coaching, briefings, training to increase the ability to absorb knowledge through proactively providing information and experience of other people that are relevant to the field of competence currently being studied by employees. . Productive recombination that occurred at PT. KAI Divre III depends on the ability of employees to learn from changes and knowledge that have been developed by employees in the organization. If employees continue to learn and always follow changes in technology or knowledge, then the ability of employees will increase, employees can take advantage of data and information and new knowledge to be utilized in the work. In this aspect is to improve the learning abilities of individual employees through the provision of information and experiences of other parties that are up to date (up to date) or (current information).

The leaders who deal directly with employees of PT. KAI Divre III Sumatera Selatan can give more attention so that employees can be given an explanation of the problem at hand, in order to obtain which data is needed for analysis. Employees analyze the data. The results of the analysis will be able to obtain a new knowledge and then a decision / wisdom can be 
taken.

The leadership can provide an explanation to employees that Supervision is carried out to avoid the possibility of fraud or deviation from the objectives to be achieved. through supervision it is expected to help implement the policies that have been set to achieve the goals that have been planned effectively and efficiently. In fact, through supervision created an activity that is closely related to the determination or evaluation of the extent to which the work has been carried out. Supervision can also detect the extent to which the leader's policies are carried out and to what extent the irregularities that occur in the implementation of the work.

Fair treatment by company management of employees will foster a positive attitude in the company and work. The fairer the company treats employees, the higher employee commitment and performance. Employees want fair treatment both in terms of distribution and procedures or known as distributive justice and procedural justice. When employees feel treated fairly, in their souls two types of outcomes will grow in the form of satisfaction and work commitment.

Based on the results of previous studies that support the hypothesis that employee competence influences employee job satisfaction, it is understandable. Employees who have good work competencies. Based on good performance, the employee will feel satisfied with the results of his work.

The results of this study state that rejecting the hypothesis, that competence does not have a significant effect on employee job satisfaction. Job satisfaction on the results of the study was not directly influenced by competence, but was influenced by other variables as intermediate variables which turned out not to be included in this study. It can also be determined that employee job satisfaction is more strongly influenced by other variables in this study, namely employee commitment.

Therefore, management needs to strive so that employee competence is improved or improved so that it has a positive effect on job satisfaction. Competency improvement can be done through formal advanced education, effective technical training and good supervision. Likewise, employee commitment needs to be improved so that job satisfaction also increases through various coaching that can be done by management to grow a higher and more stable commitment.

\section{Conclusions}

Based on the results of the study in the form of statistical analysis of data from questionnaires and based on interviews and follow-up observations as a result of the discussion, the following can be explained the managerial implications for the leadership of PT. KAI, especially PT. KAI Divre III South Sumatra, deals with the science of human resource management and organizational behavior.

The practice of HR management based on the concept of competence is a change from managing people based on what someone has (qualifications) to what someone can do 
(ability). Competency-based HR management related to the process of recruitment, selection, development, succession planning, work management, career management, and compensation are all based on competency. Therefore the leader of PT. KAI needs to provide understanding to employees, so that they can take the initiative to eliminate the competency gaps they have by participating in the development program. Based on the potential opportunities that are owned, employees can prepare themselves to tread a higher position.

The employee development program will depend on the resource management strategy itself. A good resource management strategy will be used as a support for the preparation of employee development programs. Therefore, companies must be able to develop a human resource strategy that refers to the corporate strategy of PT. KAI.

Given the aspects of employee commitment and competence are not eternal and are strongly influenced by internal and external organizational factors, then to continue to strengthen employee commitment and competence in the PT. KAI Divre III South Sumatra needs various steps that can improve both aspects. Efforts that can be done in an effort to increase employee commitment within the PT. KAI South Sumatra is through empowering employees because through the empowerment process it will encourage individuals to feel responsible for their duties and work. Increasing responsibility in work, will foster employee commitment to the organization.

Optimal employee empowerment can be done through assessment of workload, both in quality and quantity. The workload should be well distributed to all employees so that it can be known whether an employee has received the workload adequately. Therefore, leaders must work proactively in the context of carrying out routine tasks and the preparation of new work programs in the framework of innovation and meeting the challenges ahead of the company, especially PT. KAI South Sumatra.

In terms of employee behavior, management needs to improve soft skills so that employees can improve their daily behavior in accordance with the organizational culture, upholding the values adopted by the organization to achieve the targets set on the company's vision and mission. Work motivation increases, satisfaction increases, work ethic increases, performance increases is the impact of soft skills which also increases. In terms of competency, another effort that can be done is to create a conducive environment, adequate work facilities, communication between employees who are fostered, so that OCB in the company will also be better.

\section{References}

Armstrong, M. (2006). A Handbook of Human Resource Management Practice. $10^{\text {th }}$ Edition. London and Philadelphia: Koagen Page.

Bernardin, H. J., \& Russel, J. (2003). Human Resource Management: An experimental approach. (International edition). Singapore: Mc. Graw-Hill.

Dessler, G. (2011). Manajemen Sumber Daya Manusia. Penerbit: Indeks, Jakarta.

Dubois, D. D. (1993). Competency-Based Performance Improvement: A Strategy for 
Organizational Change. HRD Press Inc.

Gibson, J. L. (2003). Organizations: Behavior, Structure, and Processes. New York: McGraw Hill Book Company.

Hair, J. F., Black, W. C., Babin, B. J., \& Anderson, R. E. (2010). Multivariate Data Analysis. New Jersey: Prentice Hall.)

Luthan, S., \& Farlin, Mc. (2002). Organizational Behavior. Singapore: Mc.Graw-Hill.

Luthans, F. (2007). Corporate Culture: Challenge to Excellence. Jakarta: PT. Elexmedia Komputindo.

Mathis, R., \& Jackson, J. (2009). Human Resource Management. Mason, OH: Thomson South-Western.

Mobley, W. H. (1977). Intermediate Linkages in the Relationship Between Job Satisfaction and Employee Turnover. Journal of Applied Psychology, 62, 237-240. https://doi.org/10.1037/0021-9010.62.2.237

Modway, R. W., \& Robert, M. N. (2006). Human Resource Management. Pearson/Prentice Hall.

Neal Jr. E. J. (2003). Guide to Performance Apparsial: doing it right. Jakarta: Prestasi Jakarta.

Rice, C. L. (1999). A Quantitative Study of Emotional Intelligence and Its Impact on The Performance. Journal of Personality, 66, 525-554.

Robbins, S. P. (2003). Perilaku Organisasi. Jakarta: PT. Index Group Gramedia.

Sanghi, S. (2007). The Handbook of Competency Mapping. New Delhi: Response Books.

Shore, L. M. F., \& Martin, H. J. (1989). Job Satisfaction and Organizational Commitment in Relation to Work Performance and Turnover Intentions. Journal of Human Relations, 42. https://doi.org/10.1177/001872678904200705

Spencer, L. M., \& Spencer, S. M. (1993). Competence Work: Model for Superior Performance. John Wiley \& Sons Inc.

Wexley, K. N., \& Yulk, G. A. (2010). Perilaku Organisasi dan Psikologi Personalia. Jakarta: Bina Aksara.

\section{Copyright Disclaimer}

Copyright for this article is retained by the author(s), with first publication rights granted to the journal.

This is an open-access article distributed under the terms and conditions of the Creative Commons Attribution license (http://creativecommons.org/licenses/by/4.0/). 